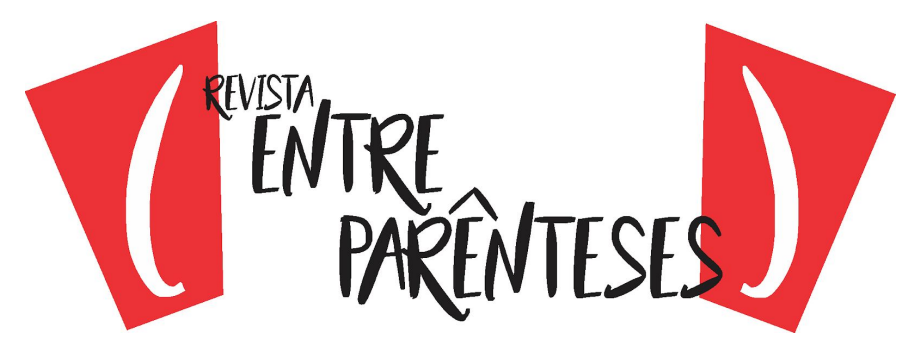

\title{
LA LITERATURA COMO FUENTE PARA EL ATRIBUCIONISMO ESCULTÓRICO
}

\author{
Rubén Sánchez Guzmán ${ }^{1}$ \\ Ayuntamiento de Madrid \\ (ruben_sanguzman@hotmail.com) \\ Antonio Rafael Fernández Paradas ${ }^{2}$ \\ Universidad de Granada \\ (antonioparadas@ugr.es)
}

\begin{abstract}
Resumen: Durante el siglo XVIII el conocimiento de los escultores castellanos de los siglos anteriores era simplemente inexistente, si exceptuamos a figuras de Juan de Juni y Gregorio Fernández. Las atribuciones masivas a estos dos escultores harto frecuente, y en el tema de los pasos procesionales, no iban a ser diferentes. Aunque las opiniones varían entre unos y otros autores, los resultados de ellas son todas variaciones de estos dos nombres. Con el presente trabajo de investigación, pretendemos poner de manifiesto la importancia de la literatura histórica como fuente de información para aproximarnos al atribucionismo de esculturas religiosas a determinados autores. Concretamente vamos a analizar el caso de Valladolid en el siglo XVIII.
\end{abstract}

Palabras clave: Escultura religiosa; imaginería; Semana Santa; Escultor; Valladolid.

\section{A LITERATURA COMO FONTE PARA O ATRIBUCIONISMO ESCULTÓRICO}

Resumo: Durante o século XVIII, o conhecimento dos escultores castelhanos dos séculos anteriores era simplesmente inexistente, exceto pelas figuras de Juan de Juni e Gregorio Fernández. As atribuições massivas a esses dois escultores eram muito frequentes e, no que diz respeito aos passos processuais, não seriam diferentes. Embora as opiniões variem entre uns e outros autores, os resultados delas são todas variações desses dois nomes. Com este trabalho de pesquisa, pretendemos destacar a importância da literatura histórica como fonte de informação para abordar a atribuição de esculturas religiosas a determinados autores. Concretamente, vamos analisar o caso de Valladolid no século XVIII.

\footnotetext{
${ }^{1}$ Rubén Sánchez Guzmán: es licenciado en Historia del Arte por la Universidad Autónoma de Madrid. En la actualidad ejerce como profesor de Historia del Arte y Conocer Madrid en los Centros Culturales del Ayuntamiento de Madrid. Ha sido docente del I Máster en Escultura Barroca Española. Desde los siglos de oro la sociedad de la información y las redes sociales impartido por la Universidad Internacional de Andalucía y Perito Tasador en Antigüedades y Obras de Arte. Departamento de Arte. Sala de Subastas Lamas Bolaño Madrid. Realizando las funciones de tasación, catalogación y asesoramiento personalizado.

${ }^{2}$ Antonio Rafael Fernández Paradas: Doctor en Historia del Arte por la Universidad de Málaga, con la tesis doctoral titulada Historiografía y metodologías de la Historia del mueble en España (1872-2011). Un estado de la cuestión. Graduado en Historia del Arte y Licenciado en Documentación por la Universidad de Granada. Máster en Peritaje y Tasación de Antigüedades y obras de arte por la Universidad de Alcalá de Henares. Actualmente es Profesor Ayudante Doctor de la Universidad de Granada, donde imparte docencia en el Departamento de Didáctica de las Ciencias Sociales de la Facultad de Ciencias de la Educación, y docente del Máster Arte y Publicidad de la Universidad de Vigo. Código Orcid: 0000-0003-3751-7479
} 


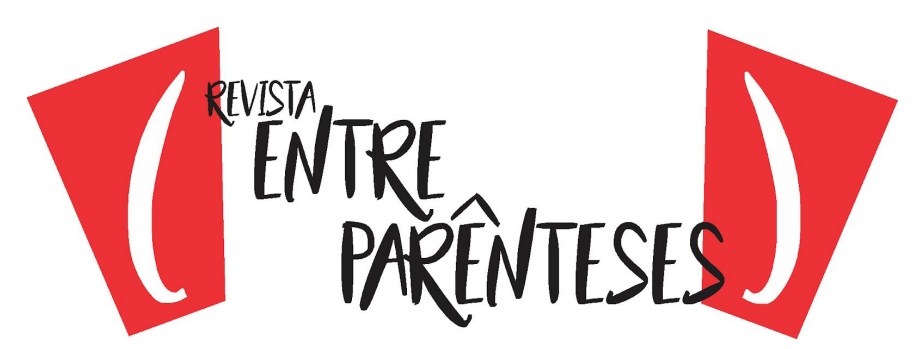

Palavras-chave: Escultura religiosa; imaginário; Semana Santa; Escultor; Valladolid.

\title{
LITERATURE AS A SOURCE FOR SCULPTURAL ATTRIBUTIONISM
}

\begin{abstract}
During the 18th century the knowledge of the Castilian sculptors of the previous centuries was simply non-existent, except for the figures of Juan de Juni and Gregorio Fernández. The massive attributions to these two sculptors were very frequent, and in the matter of the processional steps they were not going to be different. Although the opinions vary between one and the other authors, the results of them are all variations of these two names. With this research work, we intend to highlight the importance of historical literature as a source of information to approach the attribution of religious sculptures to certain authors. Concretely, we are going to analyze the case of Valladolid in the 18th century.
\end{abstract}

Keywords: Religious sculpture; imagery; Easter; Ecultor; Valladolid.

\section{INTRODUCCIÓN}

La Semana Santa, fue y sigue siendo un elemento prioritario de cohesión social. Como elemento orgánico vivo que es, ha sido capaz de adaptarse al devenir de los tiempos, haciendo suya los caracteres imperantes en cada época. En la actualidad, es un fenómeno mass mediático que se consume en las redes sociales a lo largo del todo el año, superando la barrera del periodo netamente cuaresmal. La Semana Santa es también en la actualidad un medio mediante el cual los pueblos construyen y proyectan su identidad, haciendo que lo local adquiriera tintes globales, ya que por ejemplo los contenidos cofrades y semanasanteros de un pequeño pueblo, son consumidos en YouTube desde cualquier parte del mundo.

En un amplio sector del orbe cristiano, la Semana Santa se fundamenta en los papeles que adquieren las esculturas en las representaciones de la Pasión, los cuales pueden ir cambiando en función de la reeducación de las imágenes, y sus interacciones con los devotos. Las relaciones entre seres de carne y hueso y los seres de madera se han proyectado en múltiples direcciones que han permitido conjugar la feliz convivencia en el tiempo entre ambos individuos. También ha habido momentos infelices entre ambos, donde los humanos han atacado y destruido el patrimonio religioso escultórico. Así, podemos encontrar relaciones devocionales, espirituales, familiares, lúdico-festivas, de poder, etc., pero también 


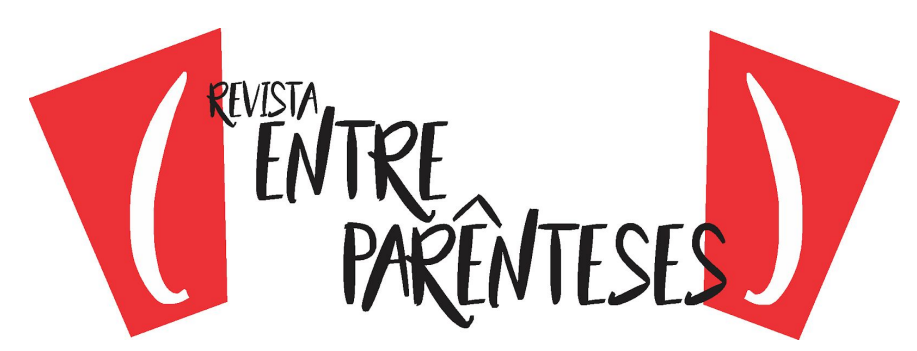

intelectuales. Y son éstas, precisamente las que nos interesan en el presente trabajo.

A lo largo del tiempo, mientras unos proyectaban sus miedos y alegrías sobre los testimonios escultóricos de la divinidad cristiana, otros hicieron lo propio en el campo del intelecto. Especialmente en la época moderna, y particularmente a partir del siglo XVIII, la Semana Santa no fue capaz de abstraerse de las nuevas corrientes intelectuales que recorrieron Europa, los aires de la razón, el método científico y el neoclasicismo intentaron abrirse hueco en una tradición anclada a centurias.

Fue en esta época donde en algunas poblaciones se produjo un interesante debate sobre la autoría de las imágenes, llenando cientos de páginas al respecto. La literatura se configuró en un arma poderosa para la proyección del talante artístico de aquellos sitios. Quizás uno de los mejores ejemplos donde se produjo esta situación, fue en Valladolid, donde la mítica figura del escultor Gregorio Fernández marcó los tientos de imaginario social, pero también del intelectual, del que debidamente se ha conservado un excelente correlato literario.

\section{OBJETIVOS}

El objetivo de la presente publicación es analizar diversas fuentes de información como base para la construcción del conocimiento sobre el atribucionismo escultórico en la Semana Santa Vallisoletana en el siglo XVIII. La Semana Santa de Valladolid tuvo un extraordinario correlato literario en diferentes épocas, aportando cada etapa visiones propias en nuevos formatos. Tal es el caso de la prensa escrita, que vino a crear un espacio de divulgación terriblemente rico al estar lleno de afirmaciones en primera persona, lo que nos permite analizar las mentalidades de la época.

De manera específica los objetivos propuestos son los siguientes: 


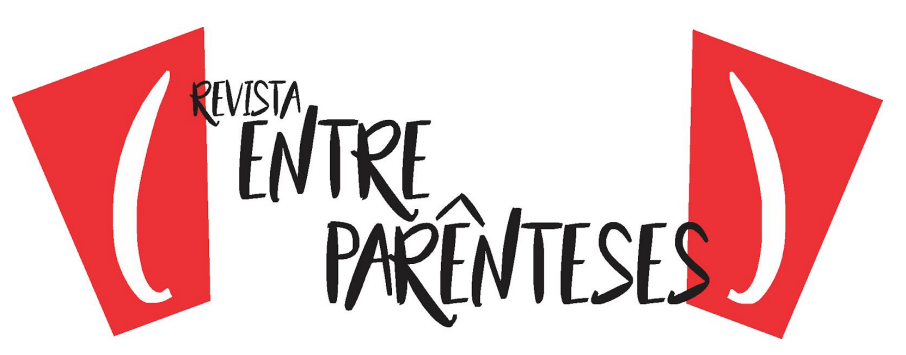

1. Valorar la importancia de determinadas fuentes como elemento para la construcción del conocimiento histórico.

2. Analizar los medios de comunicación de la época como fuente de información para comprender las mentalidades de la época por medio de la Semana Santa.

3. Comparar y analizar fuentes de información del siglo XVIII relacionadas con la Semana Santa de Valladolid.

4. Analizar los fundamentos literarios sobre el atribucionismo escultórico en el siglo XVIII

\section{METODOLOGÍA}

La metodología utilizada es de corte cualitativo y comparativo ya que se analizan los contenidos de diversos textos y publicaciones periódicas del siglo XVIII que realizan alusiones sobre la autoría de diversos pasos e imágenes (Sanz, R., 2017).

La metodología de la presente investigación se ha desarrollado a lo largo de cinco fases (Costas Fontán, N. 2015):

\section{Fase preliminar. Incluye:}

La Semana Santa de Valladolid y su manifestación artística clave, los pasos procesionales, no pasaron desapercibidos a escritores, teóricos y viajeros del siglo XVIII. Teóricos nacionales como Antonio Palomino, El Parnaso Español Pintoresco Laureado (1724), Antonio Ponz, Viaje de España (1788), Juan Agustín Ceán Bermúdez Diccionario Histórico de los más ilustres profesores de las Bellas Artes en España (1800) o Isidoro Bosarte, Viaje artístico a varios pueblos de España. Con el juicio de las obras de las nobles artes que en ellos existen y épocas a que pertenecen. Viaje a Segovia, Valladolid y Burgos (1804) y otros locales como Ventura Pérez, Manuel Canesi Acevedo o Mariano Beriatáin, se harán eco de ellos y 


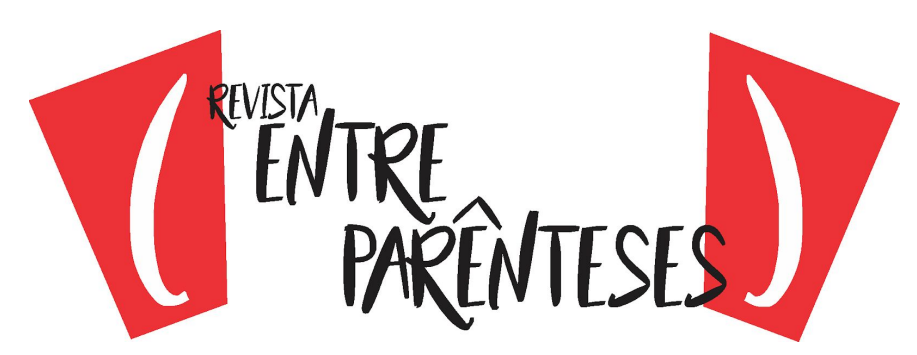

nos darán referencias en sus obras. Si bien los tratadistas nacionales son de sobra conocidos, queremos destacar los autores de las fuentes manejadas vallisoletanas.

Delimitación del objeto de estudio. Aunque el texto presenta multitud de referencias a fuentes históricas literarias y artística de la época, la base del análisis ha partido de tres fuente principales: El Diario de Valladolid fue redactado por Ventura Pérez (Egido, 1983, pp. I-XIV) entre 1720 y 1784; la Historia Secular y Eclesiástica de la muy Antigua, Augusta, Coronada, muy llustre, muy Noble, Rica y muy Leal Ciudad de Valladolid, escrita por Manuel Canesi Acevedo (1681-1750) y el Diario Pinciano, primer periódico de Valladolid, obra de José Mariano Beristáin, cuyo primer número se editó el 7 de febrero de 1787, siendo el primer periódico de Valladolid. Se ha realizado un vaciado de estas fuentes, cuya base es la justificación documental del presente trabajo.

\section{Fase exploratoria. Incluye:}

Durante esta etapa, hemos consultado obra de obras de referencias y publicaciones científicas especializadas en escultura y Semana Santa. Esta fase del trabajo nos ha permitido contrastar las fuentes analizada como objeto de esta investigación. Se realizado una búsqueda de información bibliográfica especializada que nos ha permitido matizar, explicar o ilustrar las afirmaciones vertidas por las fuentes analizadas. Así por ejemplo en relación a la autoría de los pasos, las informaciones recogidas en las fuentes se han contrastado con investigaciones sobre el tema, lo que nos ha permitido valorar críticamente los comentarios primigenios.

\section{Fase descriptiva. Incluye:}

Se han analizado diversas fuentes de referencia. Previo a la sistematización de las informaciones contenidas en las fuentes, se han tenido en cuenta las estructuras de las mismas y los modos de organización de la información. Se ha realizado un análisis descriptivo de las fuentes con carácter histórico.

\section{Fase comparativa e interpretativa. Incluye:}




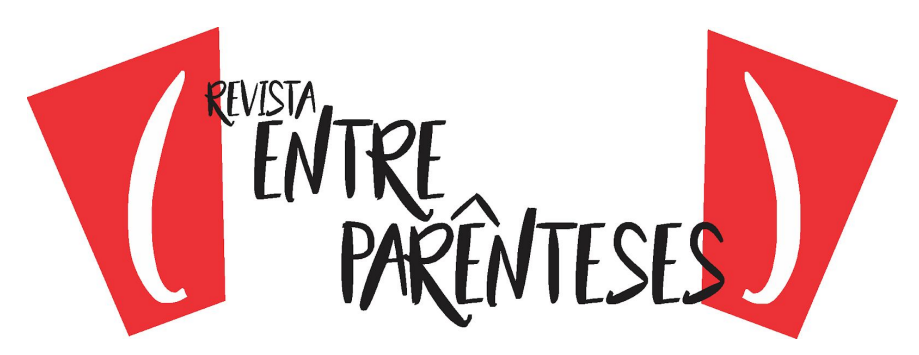

En esta fase de la investigación se han agrupado las informaciones vertidas en las fuentes. De manera específica se han analizado las atribuciones que se realizan en las fuentes.

\section{Fase conclusiva. Incluye:}

Para finalizar el trabajo, se proponen una serie de conclusiones que compilan los resultados obtenidos en el análisis.

\section{EL ATRIBUCIONISMO EN LA SEMANA SANTA DE VALLADOLID}

Durante el siglo XVIII el conocimiento de los escultores castellanos de los siglos anteriores era simplemente inexistente, si exceptuamos a las figuras de Juan de Juni y Gregorio Fernández. Las atribuciones masivas a estos dos escultores fue una cuestión harto frecuente, y en el tema de los pasos procesionales no iban a ser diferente. Aunque las opiniones varían entre unos y otros autores, los resultados de ellas son todas variaciones de estos dos nombres.

Ya Palomino había considerado que Fernández y Juni "mostraron un gran ingenio en los pasos de Nuestro Salvador" como los únicos artífices de este tipo de obras, destacando eso sí la figura del primero (Palomino, 1724/1986: 88). De Fernández cita tres pasos concretos, de los cuales dos estaban representados doblemente. Así la flagelación estaba presente en dos grupos, uno el de la Vera Cruz y otro el de la Pasión. También existían dos pasos de Jesús Nazareno, uno en la Pasión, y otro en la cofradía de homónima titularidad. Nina Ayala ha supuesto en su comentario sobre la vida de Fernández que trazó Palomino, que estos pasos eran el de la Vera Cruz y el de la Pasión respectivamente (Palomino, 1724/1986: 90), pero en un tema, donde el nombre de este escultor está unido a todos y cada uno de los pasos, surge la duda de saber si realmente Palomino se refería a los apuntados por Ayala, o a los otros dos. Por otra parte, el tratadista cordobés ya habla de Juni como autor de la imagen de las Angustias, atribución aceptadísima desde época 


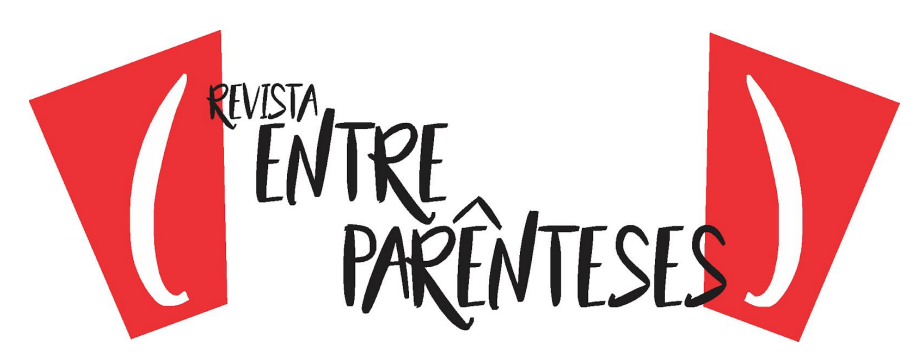

anterior, y que no ha tenido ninguna réplica salvo la de Canesi. El historiador se descuelga con otra sorprendente aseveración, afirmando que todos los pasos son de Fernández, incluso la Virgen de las Angustias (Canesi, 1996: 24).

La idea muy enraizada en Valladolid de que sobre todo Fernández fuera el escultor de cada uno de los pasos, ya fue puesta en duda por Ponz en su "Viaje", "yo soy de muy contraria opinión, por la diferencia que he hallado de unas a otras" (Ponz, 1788: 53). En efecto, el ilustrado ya hablaba de un hecho evidente, pero lo que únicamente hace es abrir el círculo, si antes eran obras de Fernández, ahora también entra en juego el taller, que ejecuta las ideas del maestro. De todas formas, será este el primero que se atreva a proponer nuevas atribuciones, como las de los ladrones a Leoni. Vano intento pues esas obras concretamente si eran de Fernández. Beristáin, ferviente seguidor de las ideas ilustradas y lector de Ponz, nos da unas nuevas atribuciones, de lo más sorprendentes para nosotros, pero no para su época. Según él, los únicos pasos de Fernández eran los que se custodiaban en la Vera Cruz, siendo seguros de este escultor el Descendimiento y el de la Flagelación, aseverando además que el resto de los pasos de la Semana Santa eran de Juni (Beristáin, 1933: 103-104). Por su parte Ceán, no dice nada respecto a lo expuesto ya por Ponz, salvo que introduce un nombre, el de Manuel Iribarne, como hombre relacionado con Fernández y por tanto de sus obras procesionales. Pero será quizás Bosarte el primero que se acerque al arte procesional desde un punto más juicioso. Ya habla don Isidoro de algo que se ha confirmado posteriormente, que Juni no realizó ningún paso procesional, extremo que también lo aplicó erróneamente a la imagen de las Angustias de Juni (Bosarte, 1804: 207), que realmente fue el único paso realizado por Juni.

De todas formas, esta creencia de que Fernández fue el inventor y creador de todos y cada uno de los pasos que poseían las cinco penitenciales, se mantuvo durante todo el siglo XIX, a aun en el catálogo de escultura del Museo de Valladolid, publicado en 1916, Agapito y Revilla seguía considerando a los conjuntos 


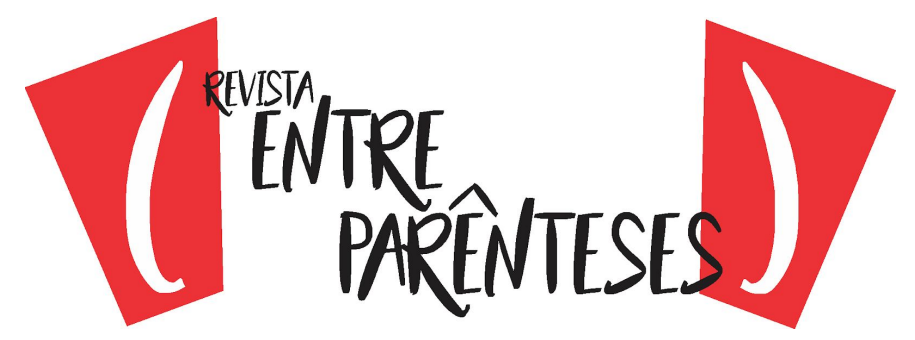

depositados en el museo como obra del maestro (Agapito y Revilla, 1930). Será a partir de esta fecha, con el descubrimiento de nuevos autores como Juan de Ávila, Alonso y José de Rozas, Francisco del Rincón... Cuando se empezó a documentar en unos casos o atribuir de manera correcta.

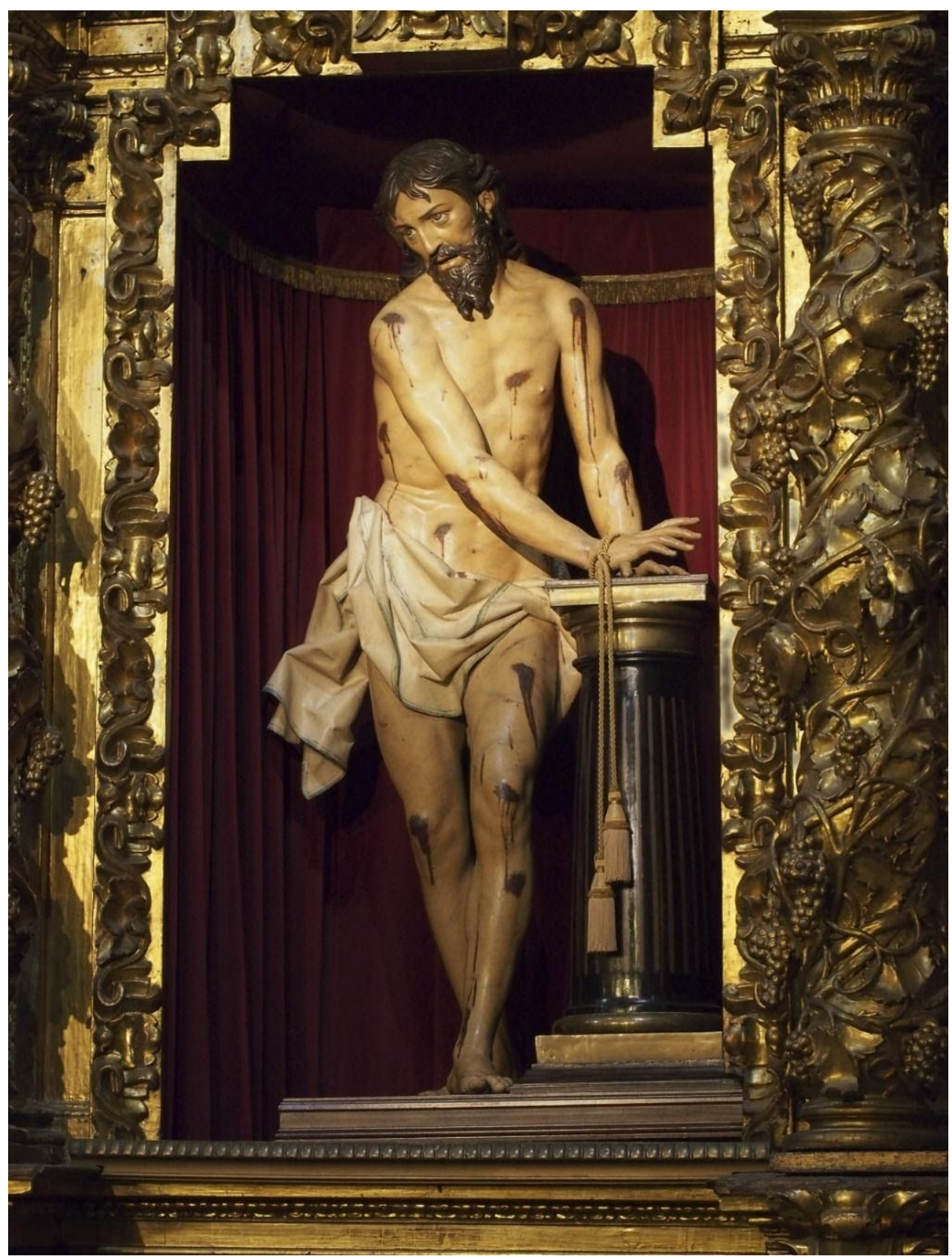

Fig. 1 Gregorio Fernández. Cristo Atado a la Columna. Iglesia de la Vera Cruz (Valladolid). Foto: Luis Fernández García. Licencia Creative Commons Attribution-Share Alike 3.0 Unported 


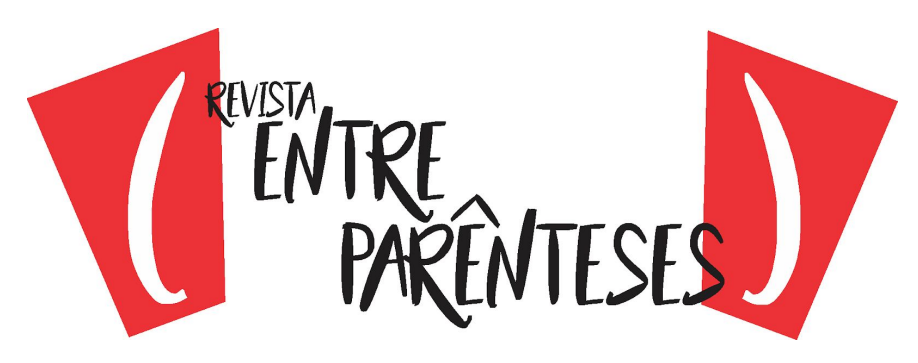

Decana de las cofradías vallisoletanas, la Vera Cruz, ha sido la que más ha suscitado el interés de los escritores, y por eso por lo que disponemos de gran cantidad de referencias. La cofradía comenzó el siglo XVIII con cuatro pasos, según se desprende de la descripción de Canesi, "la Oración que hace Cristo en el Huerto, el Azotamiento, la Coronación, el de José de Arimatea y Nicodemos, bajando a Cristo de la Cruz, presente su Madre Santísima" (Canesi, 1996, p. 23). Estos mismos paso son citados por Ponz y Ceán, aunque por verlos el primero en la iglesia penitencial que poseía la cofradía en la calle Platerías, a lo que se refiere son a las figuras principales de los conjuntos de dichos pasos que recibían culto en los altares durante todo el año, mientras que el resto de las figuras que formaban las escenas eran retiradas y guardadas en la salas adyacentes, de esto que Ponz cite las imágenes aisladas del Ecce Homo, Cristo de la Columna (Fig. 1) y la Oración en el Huerto. En cambio, el cuarto paso procesional citado por Canesi, el del Descendimiento, no era desmontado después de los días de la procesión y permanecía montado en una capilla de la iglesia durante todo el año, de ahí que Ponz hable de este paso en su conjunto, "hay figuras pertenecientes al paso del Descendimiento" (Ponz, 1788: 56). Este conjunto ha sido el único que ha permanecido íntegro y con la misma escenografía ideada por Fernández (Fig. 2).

No cita Canesi un quinto paso que introdujo la cofradía, el de la Dolorosa de la Vera Cruz. Esta imagen, no era otra que la figura de la Virgen desmayada del paso del Descendimiento, que fue retirada del conjunto en 1745 , al haber realizado la cofradía una reforma en el camarín del altar mayor. Esta intervención consistió en la realización de un "trono de espejos al Santo Cristo" colocándose además "a sus pies a su Madre María Santísima de los Dolores" (Canesi, 1996: 26). El nuevo conjunto formado por dos de las imágenes más veneradas en Valladolid, fue rápidamente grabado en distintas estampas para el uso devocional (Luna Moreno y Fernández González, 1986: pp. 18-20). Al colocar esta imagen de la dolorosa en el 


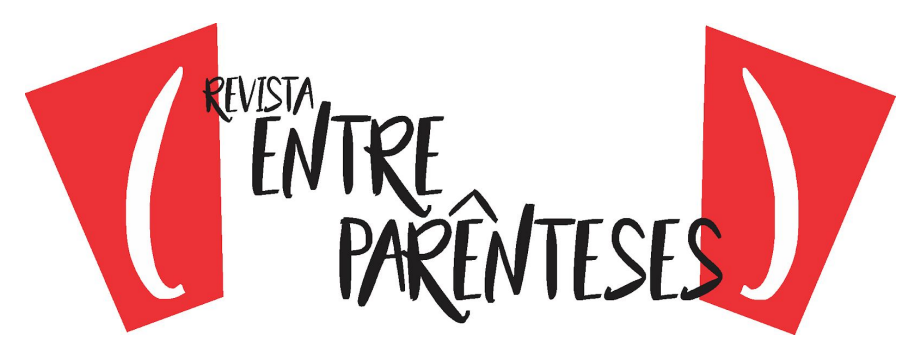

altar, el paso del Descendimiento quedó incompleto, por lo que, en 1757, se realizó una copia de la imagen para colocarla en el conjunto procesional, siendo esta imagen la única procesional que se realizó durante el siglo XVIII (Andrés Ordax, 1994: 54).

Esta imagen colocada en el altar mayor, llamó la atención a los viajeros del siglo XVIII que la vieron entronizada en este lugar, dedicándola encendidos elogios, pero ninguno comparable al de Bosarte, que la cita como Stabat Mater: El diseño, paños, artificio de las rocas todo es excelente; y por lo que hace a la hermosura de su cabeza, si los ángeles del no bajan a acerla más bella, de mano de hombre, no hay nada que esperar", añadiendo seguidamente, "ipero qué lástima! Una mano moderna imperita cometió el atentado de repintar dota esta imagen, con lo que consiguió estropearla enteramente de alto abaxo. Le puso unas lágrimas negras, dio un color blanquecino desmayado su rostro, las cejas las rehízo cada una de una pincelada, así de los demás. De manera que no se sabe si el dolor que expresa la figura es mayor ó menor que el que excita lo desfigurado (Bosarte, 1804: 102-103). Pese a todo, estos repintes no fueron los únicos que hicieron lamentarse al ilustrado. Refiriéndose a la Oración del Huerto dice: la cabeza del señor es buena, y el ángel que también es de tamaño natural, sería bueno si no lo hubieran repintado; de modo que no se conoce lo que fue, ni nadie diría que es de Gregorio Hernández (Bosarte, 1804: 205). 


\section{(}

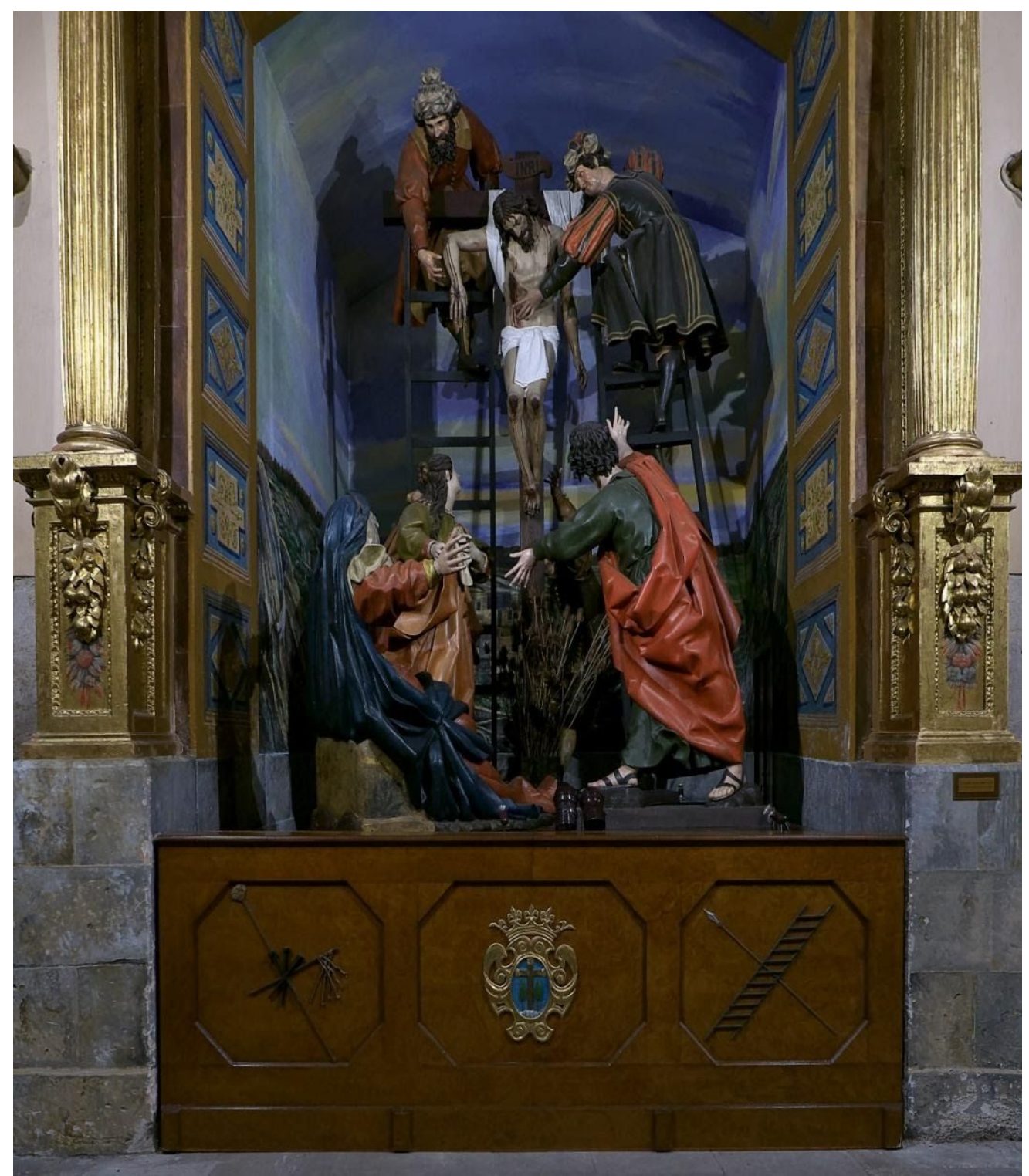

Fig. 2. Gregorio Fernández. Descendimiento. Iglesia de la Vera Cruz (Valladolid). Foto: José Luis Filpo cabaña. Creative Commons Attribution 4.0

En efecto los repintes tan habituales en otras épocas, y nada criticados, son ahora motivo de preocupación por los ilustrados. De todas formas, las palabras de Bosarte no fueron las primeras, ya que Beristáin había puesto el grito en el cielo con los repintes que habían sufrido varias imágenes de la Virgen del Descendimiento, el Ecce Homo de la Coronación y el ángel de la Oración del Huerto, "con pretexto de composición o retoque" (Beristáin, 1933: 23). 


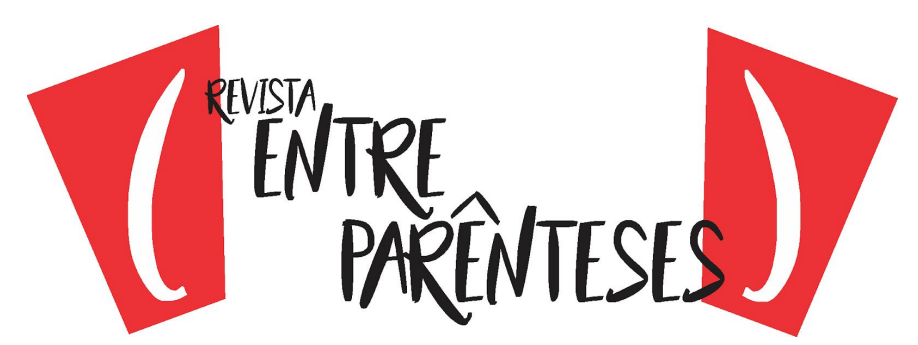

Los pasos procesionales que poseía y posee aun la cofradía habían sido considerados desde antiguo como las más bellas y perfectas obras de Fernández. Ya Ponz, las consideró como "bellas obras de Gregorio Fernández" (Ponz, 1788: 56), y Beristáin como las únicas obras que habían salido de sus manos, afirmando además que eran de "Gregorio Hernández seguramente los del Descendimiento y el de la Columna" (Beristáin, 1933: 102-103). Más elogioso se había mostrado ya Canesi, respecto a estos conjuntos que se custodiaban en la Vera Cruz y a su artífice:

y hay en ellas algunos misterios de la Pasión de Christo, cuyas efigies fabricó Gregorio Hernández, célebre escultor y buen Christiano, pues cuando empezaba alguna hechura se prevenía para el acierto con los Sacramentos de la Penitencia y Eucharistias. Salieron todos tan primorosos, que se tienen en tanto crédito como ser sin segundo en toda Castilla (Canesi, 1996: 23).

En la escala de valores que establece Canesi, Fernández era el primero y se distancia de los demás porque tampoco había un segundo maestro en mérito. Si como veremos en otros casos las atribuciones a Fernández han sido desmentidas, en esta ocasión se han confirmado que de los cuatro pasos citados por Canesi, solo uno, la Oración en el Huerto, no era de Fernández. Las labores de investigación de García Chico han documentado los pasos del Descendimiento y la Flagelación (García Chico, 1941: 180-181). Aunque del paso de la Coronación de Espinas no se ha encontrado documento alguno, la atribución a Fernández está más que aceptada. En cambio, estas mismas labores han llevado a saber que Fernández no fue el autor del paso de la Oración del Huerto, sino de su discípulo Andrés Solanes (Urrea, 1989, pp. 483-484). Se ha podido documentar lo dicho por Ponz acerca de la realización de Fernández de modelitos para todas estas imágenes (Ponz, 1788: 56). Se conoce que Fernández antes de hacer el paso del descendimiento en madera, entregó un modelo en cera a la cofradía para su aprobación (García Chico, 1941: 172-173). 


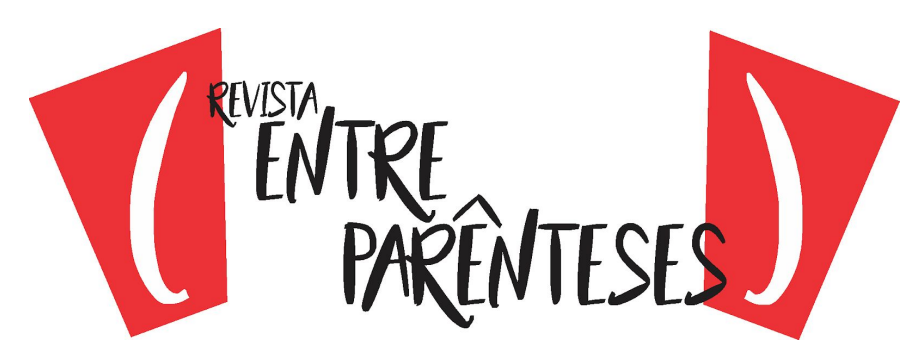

También poseía esta cofradía el único paso conservado de los antiguos conjuntos del siglo XVI, en cartón y lino, papelón: la borriquita. Según palabras de Canesi, el único que cita el paso, el Domingo de Ramos: "la cofradía de la Cruz lleva un paso muy vistoso del Triunfo de Cristo en la Entrada de Jerusalén, al convento de San Francisco y concurren a la procesión conventual por la mañana y al fenecer la misma la vuelta a su templo con grave autoridad" (Canesi, 1996: 20).

La Cofradía de la Pasión era según Canesi "tan antigua como la Vera Cruz" (Canesi, 1996: 27), y poseía uno de los conjuntos procesionales más importantes de la ciudad. Durante el siglo XVIII llegó a ser propietaria de un total de seis pasos. Pese a ello la referencia dadas por teóricos al uso, salvo Bosarte, son muy vagas. Ponz no cita ni un solo paso o figura perteneciente a ellos, solo recoge que "se ven cuatro estaturas de esta clase en la sacristía, y más catorce en la sala inmediata" (Ponz, 1788: 56-57). Tan lacónica explicación es recogida por Ceán copiándola literalmente, sin añadir nada nuevo (Ceán, 1800: 266). En cambio, Bosarte, aunque confunde la sacristía de la Pasión con la de la Vera Cruz, está más informado que los demás investigadores, ya identifica las cuatro estatuas que había visto Ponz en las hornacinas de la sacristía del templo. Habla así de ellas:

La verónica. Esta es una de la mejores de este artista (Fernández). Se haya con otras en la sacristía de la Iglesia de la Cruz. Representa la estatua una mujer de más de treinta años de edad, y es una buena imitación del natural. Buenos paños, mucho decoro, y sobre todo la santidad del alma. No e visto cosa alguna que merezca compararse con esta (Bosarte, 1804: 204-205).

Diciendo a continuación que también había una imagen de Cirineo, en su hornacina, como la Verónica, y un San Juan y una Magdalena, a lo que añade que "ninguna de estas llega a la verónica" (Bosarte, 1804: 205), imagen que después de la dolorosa de la Vera Cruz es la obra procesional más alabada de Fernández. Estas cuatro figuras más una dolorosa que según la documentación también se encontraba en este espacio, formaba parte de dos de los pasos descritos por Canesi. Las dos 


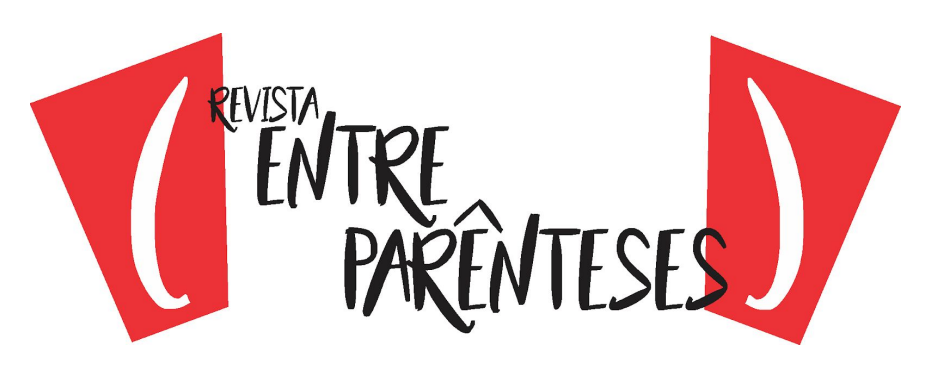

primeras son citadas en el segundo de la cofradía, "Jesús Nazareno y el Cirineo ayudándole a llevar la cruz, un judío con la lanza hiriéndole el costado y las dos mujeres que salieron al encuentro a Jesús y a una le limpió el rostro en la calle de la amargura, Ilamada Verónica" (Canesi, 1996, p. 27).

Mientras las otras tres imágenes formaban parte del paso nuevo de Nuestra Señora y San Juan, descrito así Canesi: "Cristo en la Cruz y San Juan y la Magdalena llorando y su santísima madre y dos judíos partiendo sus vestiduras y túnica in consutil" (Canesi, 1996: 27). Como se puede comprobar en la descripción de Canesi del primer paso, aparece un sayón con lanza y otra mujer, junto a la Verónica, de la primera talla, aunque se han realizado esfuerzos para identificarla, no se ha conseguido. Mientras que la misteriosa mujer que acompañaba a la Verónica, es su referencia la única que conservamos, y muy posiblemente sea error suyo. El conjunto es obra documentada de Fernández, salvo la imagen de Cristo, desaparecida desde antiguo (Viñaza, 1889: 253; Luna Moreno y Fernández González, 1986: 51-53 y V.V.A.A, 2000: 53-62). Respecto al segundo conjunto, han desaparecido los sayones, que según Wattenberg fueron los remitidos a Madrid (Wattenberg, 1966, p. 67). La atribución dada a Francisco de Tudanca como autor de la obra, no está exenta de polémica (Luna Moreno y Fernández González, 1986: . 58-62 y V.V.A.A, 2000: 45-52).

Otra de las imágenes que podemos localizar en el templo era la de su titular, Nuestra Señora de la Pasión, obra anónima del siglo XVI, que presidía el retablo mayor y que según Canesi comenzó a realizar estación de penitencia en 1705 (Canesi, 1996: 24). Nadie había podido averiguar de qué materia estaba formada la imagen, que estaba envuelta en un manto, dejando solamente ver el rostro. Pero Canesi sospechaba que "al parecer está sentada y con su amado en el regazo, ya difunto, como en esta estampa se ve". De esta se conservan varias que representan a una piedad cubierta con un amplio manto (Martin González, 1982,: 405), una vez cerrada la iglesia al culto, desapareció el rastro de tan milagrosa 


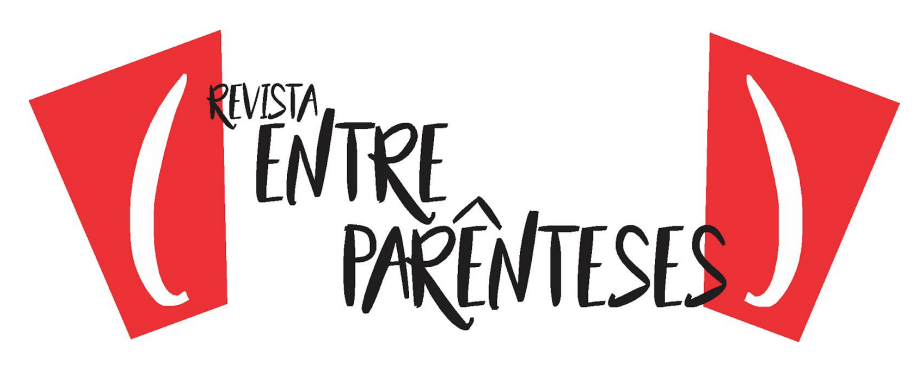

imagen, hasta que fue identificada por Luna Moreno, con una piedad que se venera en una capilla del Santuario Nacional (García Vega, 1995: 622). Hoy la imagen se encuentra depositada en el convento de San Quirce, sede actual de la cofradía de la pasión.

Poseyó la Pasión el paso de la Elevación de la Cruz de Francisco de Rincón, primer paso realizado enteramente en madera. Las primeras descripciones que tenemos se deben a Canesi: "Cristo en la Cruz y los judíos tirando con unas sogas de ella para enarbolarla, y los dos ladrones a su vista en el suelo en pie" (Canesi, 1996: 24). Estas dos últimas imágenes de los ladrones llamaron la atención de Bosarte, aunque como es habitual no las relacionó con ningún paso procesional, apuntado simplemente que ambas tallas "que van por su pie desnudos al suplicio, son figuras bien contrastadas y de buen composición" (Bosarte, 1804: 206). Cuando las imágenes del "historiado" del paso fueron llevadas al Museo, la imagen del Cristo quedó al culto en la iglesia de la Pasión. Al cerrarse la iglesia el paso fue llevado a San Quirce, ya que se le había cambiado el nombre por San Dimas Crucificado, por lo que se le colocó otro Cristo. En la actualidad se ha subsanado el error, colocando el Cristo de San Quirce en la Elevación, y el que estaba aquí, fue colocado en su paso original, el de la Virgen y San Juan. (Martí y Monsó, 1898-1901: 499; Martín González, 1959: 70; Urrea, 1973: 405, y V.V.A.A.2000: 73-84). El otro conjunto importante de la cofradía (y como el resto se encuentra en el Museo) era la flagelación o "El Azotamiento", según Canesi. El escritor tan dado a descripciones de todo el grupo escultórico, más o menos somera, no dice nada acerca de cómo estaban dispuesto el discurso narrativo de las figuras, que conocemos por las instrucciones de su montaje del siglo XVII para su montaje. El paso está formado por cinco tallas, cuatro sayones y un Cristo atado a la columna, que venía a repetir el paso que Gregorio Fernández había hecho para la cofradía de la Vera Cruz. El conjunto de desigual calidad entre los personajes ha sido recientemente atribuido a 


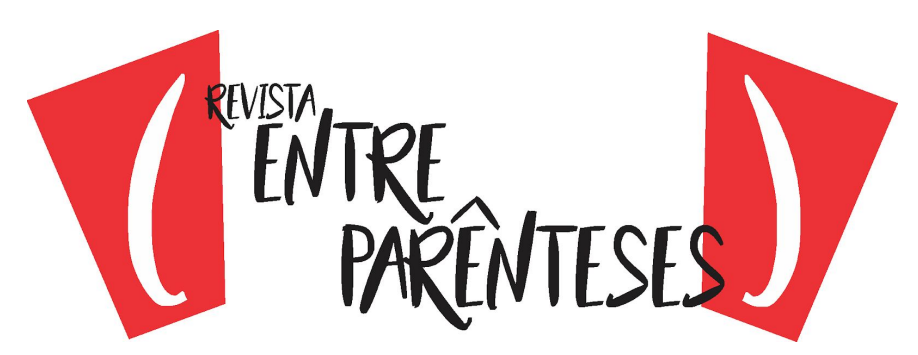

Francisco Díez de Tudanca y Pedro de Ribera, que lo realizarían en 1659 (Fernández del Hoyo, 1984: 376 y V.V.A.A, 2000: 45.52)

Finalmente, está la figura de un "Cristo orando a su eterno Padre, a este señor llamaban del Perdón", obra ampliamente documentada de Bernardo del Rincón, que la realizó en 1656 (Fernández del Hoyo 1983: 476-481). La imagen se veneró en la iglesia de la Pasión hasta 1926, en que ante la inminente ruina del templo fue trasladado a San Felipe Neri. Con posterioridad el Cristo fue llevado a la iglesia del Santuario Nacional, y luego a la Magdalena, de donde pasó al Convento de San Quirce, donde actualmente se encuentra.

La Cofradía Penitencial de las Angustias, es junto con la Cofradía de la Vera Cruz, de la que más disponemos de información más variadas, aunque exclusiva a los pasos de la Virgen de las Angustias de Juni y la Piedad con los dos ladrones, mientras que los otros tres pasos según la relación de Canesi, un crucificado, el Sepulcro y los "durmientes", la información es mucho más escasa" (Canesi, 1996, p. 24).

Fray Matías de Sobremonte ya cita a la Virgen de las Angustias (Fig.3) como obra de Juni, aunque la denomina Virgen de las Angustias. Palomino la asigna también a Juni y la Menciona como Virgen de las Angustias (Palomino, 1724/1986, p. 89). Ponz, Ceán, Beristáin y Bosarte mantienen la atribución, aunque no la advocación. Los dos primero la citan como Virgen de los Dolores, mientras el resto la llaman con el título por el que era conocida en Valladolid, el de Virgen de los Cuchillos. Tal advocación surge al colocarle en el siglo XVII a la imagen siete grandes cuchillos, los Siete Dolores de María, alrededor del pecho (Martín González, 1974: 325). Con la retirada de estos en 1972 ha recuperado su antiguo nombre de las Angustias. Pese a esta unanimidad en la adjudicación a Juni, Canesi sostiene que es obra de Fernández. La aseveración por disparatada que parezca, podría explicarse al tener en cuenta que Fernández durante mucho tiempo fue el primero y único autor conocido, ya que la valoración de Juni es mucho más tardía. 


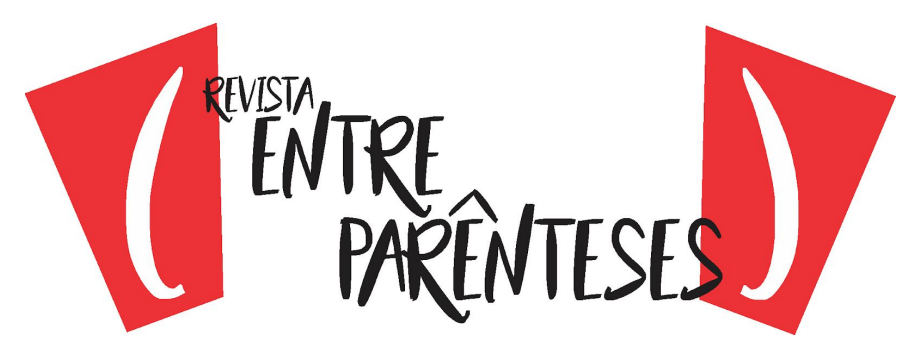

La imagen de Juni, ha sido una de las más ponderadas y alabadas por todos los escritores. Canesi la califica de "imagen de especial devoción y hechura" (Canesi, 1996: 24), Ponz de "de bella obra de escultura" (Ponz, 1788: 24) y Beristáin la considera la obra más perfecta del artista, "que a todas exede" (Beristáin, 1933: 103). Pero sin lugar a dudas será Bosarte el que mejor glosó la belleza de la imagen, con auténtica y rendida veneración estética:

¡Qué dibuxar! ¡Que paños! La expresión de la cabeza es al que toca lo sublime, y no se puede admirar de cerca sin una fuerte conmoción interior", prosigue Bosarte describiendo como "invento" Juani la imagen: "tomo la biblia, y se fue en derechura a buscar los trenos de Jeremías, que es el mayor poeta sagrado de los hebreos en cantos tristes elegiacos y leyó... ¡como yace solitaria en su asiento la ciudad llena antes de numeroso pueblo! La Señora de las gentes ha venido a quedar como viuda... las lágrimas de sus ojos corren por la mexillas de su rostro. No hay quien la consuele... la despreciaron porque vieron su ignominia, y ella gimiendo se ha vuelto hacia atrás (Bosarte, 1804: 174-176). 

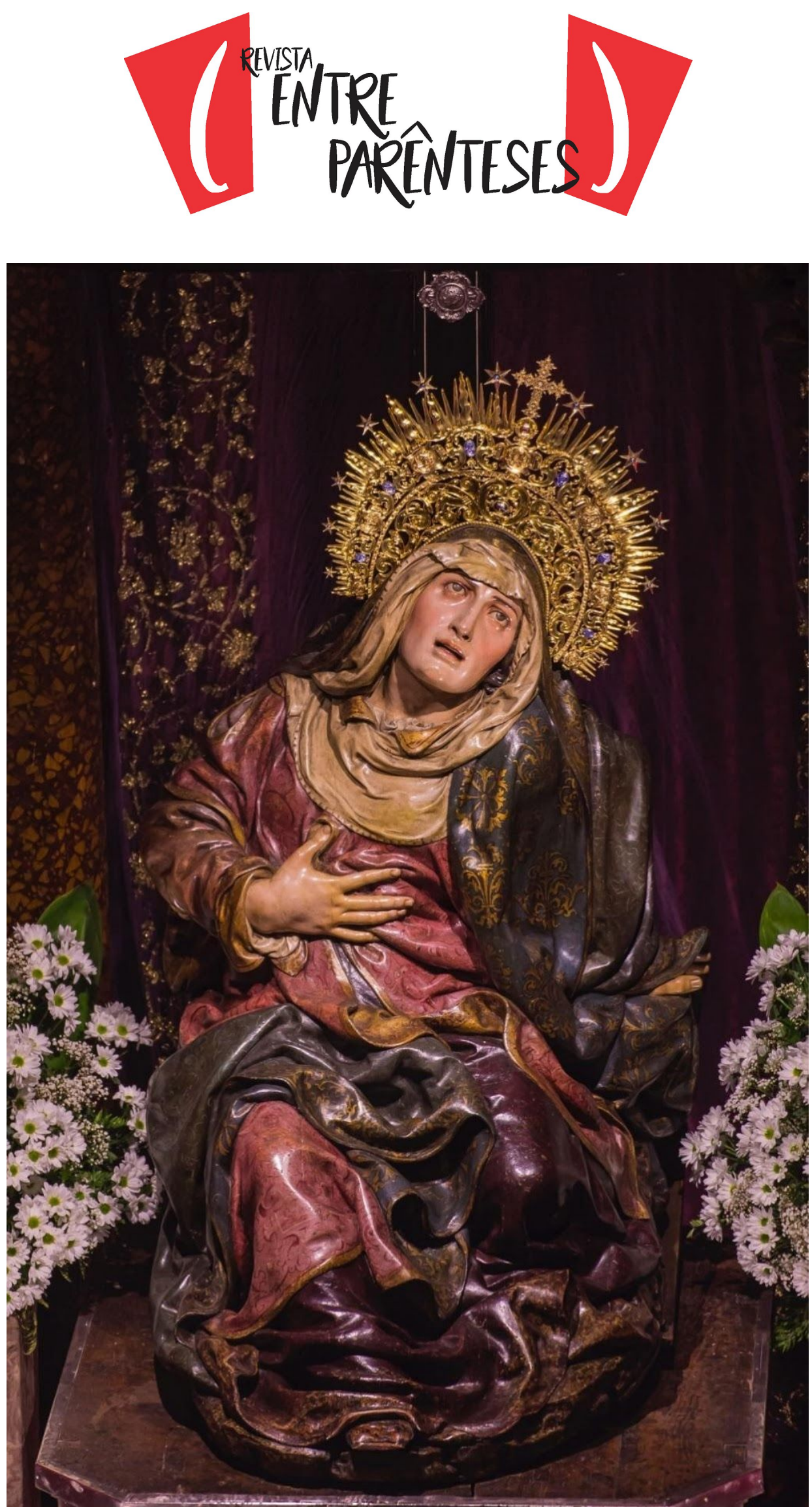

Fig. 3. Juan de Juni. Nuestra Señora de las Angustias. Iglesia de las Angustias (Valladolid). Foto: Pablo F.D 


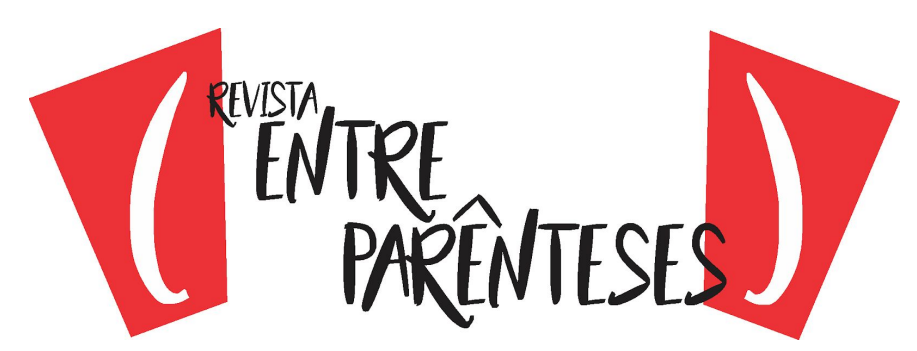

Conocida es la moda de vestir a las imágenes con ricas telas durante el siglo XVIII, aunque esta no fuera realizada para tal fin. La imagen de las Angustias gracias a esa calidad y belleza reconocida unánimemente, aunque se intentó, se libró de ello, tal y como nos lo cuenta Bosarte:

el conde de Rivadavia, don Diego de Cobos, devoto de Nuestra Señora de los Cuchillos, intentó varias veces vestirla con las mejores y más costosas telas, hasta que, convencido por la experiencia de que la imagen está hecha de modo que no admite vestidura alguna postiza (Bosarte, 1804: 176).

La leyenda y la tradición tampoco escapan al interés de los teóricos del siglo XVIII. Buen ejemplo es la tradición recogida por Bosarte (Bosarte, 1804: 202), que nos habla de la que esta imagen no fuera encargada por cofradía vallisoletana alguna para su procesión, sino que Juni la hiciera para otro pueblo de la provincia, y que, al no agradar a los nuevos propietarios, por tener un pie excesivamente grande, fue devuelta siendo adquirida por la Cofradía. Esta tradición trajo cola, y durante parte de los siglos XIX y XX, varios fueron los autores que se aventuraron a identificar ese pueblo: Medina de Rioseco, supuso García Chico; Boecillo para Matías Sangrador y Tudela de Duero par Juan Ortega Rubio. (Val y Cantalapiedra, 1979: 143).

El otro gran conjunto el de la Piedad con los dos ladrones (Fig. 4), conservado en el Museo Nacional de Escultura, se custodiaba en la capilla de la epístola de la penitencial de las Angustias, donde la mencionan todos los autores considerándola desde antiguo obra de Fernández (García Chico, 1941: 172-173). Palomino y Beristáin ni siquiera la citan. La primera noticia que tenemos del conjunto nos la da Canesi, al describir el desfile procesional de la cofradía: "Otro Cristo en el regazo de su Madre santísima cuando descendió de la cruz y los dos ladrones puestos en sus cruces" (Canesi, 1996: 24), ya por entonces se habían suprimido del conjunto las imágenes de San Juan y la Magdalena. Cuando cita Ponz al conjunto, en la capilla, solo cita al grupo central de la Piedad y los dos ladrones, que según él 


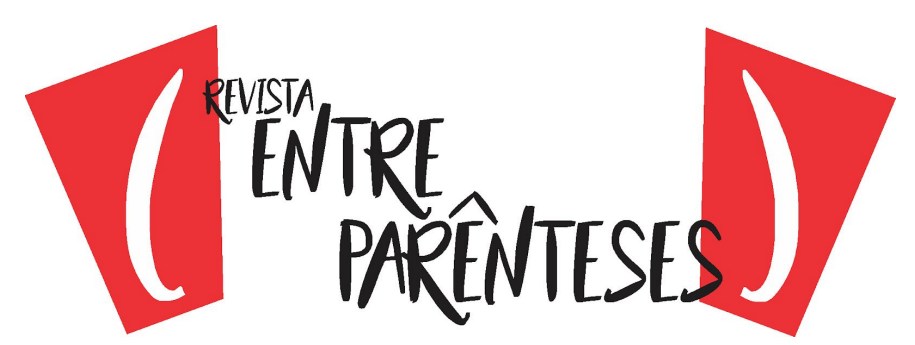

se atribuían a León Leoni "que hizo tan buena obra en el Escorial” (Ponz, 1788: 53). Esta atribución fue posteriormente seguida y matizada por Beristaín, argumentando que "no son obras de León Leoni, ni este escultor trabajo en el Escorial", excusando a Ponz diciendo que "tal vez se confundió este Viajero con Pompeyo Leoni, hijo de aquel escultor Aretino, del que qual son las estatuas de bronce del Escorial" (Beristáin, 1933: 103). En un tema donde las atribuciones masivas a Gregorio Fernández es lo dominante, esta de Ponz resulta cuanto menos excepcional, quizás motivada por un deseo de acercarse más a la realidad, ya que el mismo había considerado la desigual calidad de las tallas, y por lo tanto la intervención de distintos maestros. Por otro lado, es curioso, que las obras más clásicas de Fernández atribuidas a Leoni, quizás porque Ponz consideró que Fernández era demasiado "barroco" para atribuirle estas dos imágenes. Reparo que no tuvo el juicioso Bosarte:

a mí me parecen que son de Gregorio Hernández, no porque estén cercanos a este grupo, sino porque Leoni no se ajustaba a la morbidez del natural como Hernández; y también porque las fisionomías de los ladrones de esta historia coinciden en sus formas con otras figuras de Hernández, y con ninguna de la que he visto de Leoni (Bosarte, 1804: 203). 

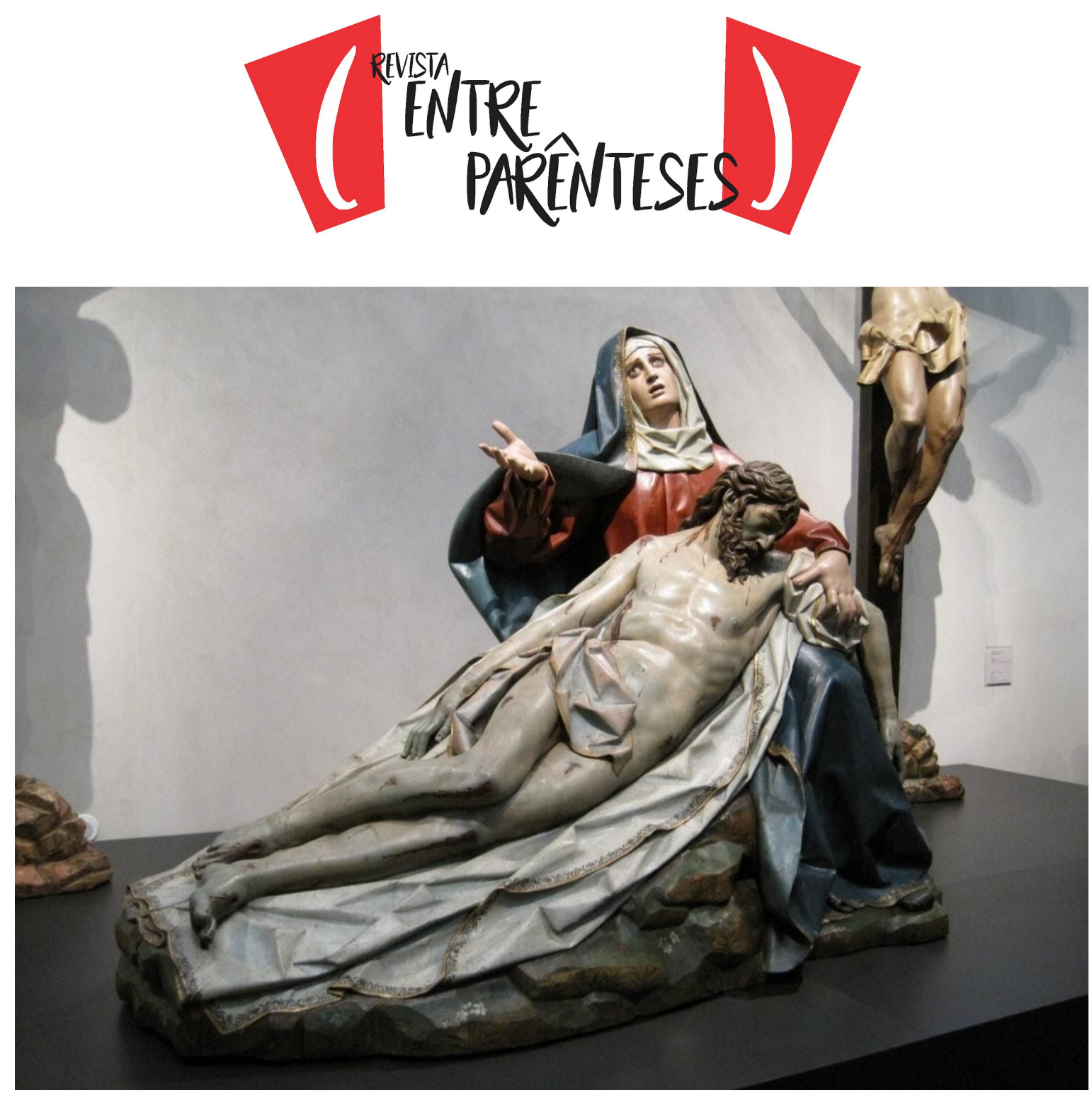

Fig. 4. Gregorio Fernández. La Sexta Angustia. Museo Nacional de Escultura (Valladolid). Foto: Rodelar, Wikimedia Commons, Licencia CC-BY-SA 4.0

Respecto a las tallas de San Juan y la Magdalena, es también Bosarte el único que las cita, localizándolas en altares de la Capilla de la Virgen de las Angustias (Bosarte, 1804: 203). Los Cuchillos según él, lamentándose que para entender estas imágenes "era menester ver la historia, y esto no puede verse sino en Semana Santa en medio de la calle", prosiguiendo que "cada figura tiene su expresión y movimiento dependiente de la composición y unidad a la que es relativa" (Bosarte, 1804: 206). Pese a estas interesantes palabras, que denotan un perfecto entendimiento de los conjuntos procesionales, no relacionó estas dos excelentes imágenes, que aún se conservan in situ, con la Piedad y los dos ladrones, teniendo que esperar al siglo XX para que Agapito y Revilla, usando el inventario realizado 


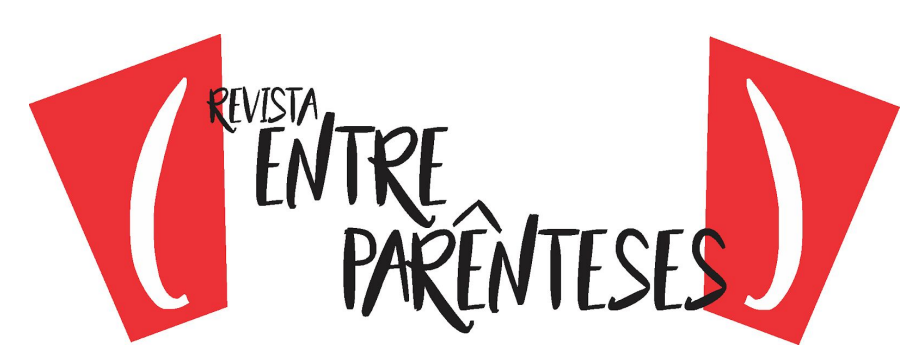

por la Academia en 1803, pusiera en relación todas las figuras que formaban el conjunto procesional.

Respecto a los otros tres pasos, las informaciones que disponemos son muy escasas y proceden de la misma fuente, de la descripción de Canesi del cortejo procesional. El crucificado que cita el Historiador, es el llamado actualmente Cristo de los Carboneros, advocación que le viene, porque en el año 1805 los mozos del carbón se comprometieron a sacarlo (Val y Cantalapiedra, 1979: 162). La imagen custodiada en las Angustias ha sido atribuida por Martín González a Francisco de Rincón. En la misma iglesia aún se encuentra la anónima imagen del Cristo en el Sepulcro, que según palabras de Canesi, era llevado por sacerdotes. El citado como "otro Cristo en el sepulcro y los guardias que le pusieron dormidos" (Canesi, 1996: 24), es el llamado desde el siglo XVIII, como los "durmientes", por los guardias dormidos. Bosarte habla del paso ponderado la imagen de los soldados: Quatro soldados pretorianos hay guardando el sepulcro; y en aquel sitio parecerán muy bien, pues aun arrinconadas en el coro de la iglesia de las angustias, y sin relación entre sí parecen bien (Bosarte, 1804: 206).

En efecto, según la documentación existente, el coro era el lugar donde se guardaban los soldados durante el año. El conjunto que se completaba con dos ángeles, (no citados por ninguno de los dos escritores, que al desmontar el paso se colocaban flanqueando el Altar Mayor) está documentado por García Chico, como obra compartida entre los escultores Alonso y José de Rozas, que llevaron a cabo la obra durante el último cuarto del siglo XVIII. Al primero se le deben los cuatro guardias dormidos y la Urna, mientras al segundo los dos ángeles que lo flaqueaban, quedando aún en el anonimato la autoría del yacente (García Chico, 1941: 172-173).

La Cofradía de la Piedad fue a la que más le afectó la crisis que asoló la Semana Santa de Valladolid durante la segunda mitad del XVIII, llegando incluso a tener que abandonar su sede en 1789 que amenazaba ruina, teniendo que buscar cobijo en la desaparecida iglesia de San Antón. Dado este clima, no es extraño que 


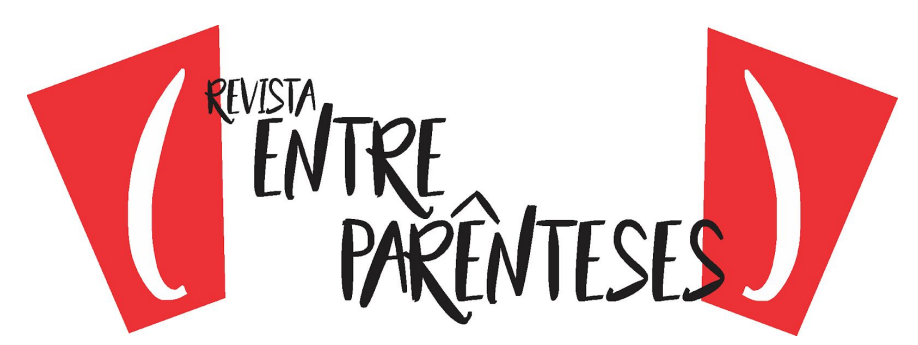

las referencias que tenemos de sus conjuntos procesionales, sean tan escasas. Tan solo Canesi y Ventura Pérez no hablan de ellos en dos momentos muy distintos. La descripción del cortejo del primero se hizo en un momento de esplendor de las celebraciones, mientras que los datos que nos da el segundo en su "Diario", se enmarcan ya dentro de la crisis.

El primer paso que vio Canesi en la procesión de esta cofradía, fue el "Cristo con la túnica encarnada sentado y detrás de la cruz y los atributos de su Pasión, repartidos en ella de talla" (Canesi, 1996: 25). Conocido como Cristo de la Humildad, fue contratado en 1691 a José de Rozas. Durante bastante tiempo se consideró perdida esta imagen, hasta que Marín González planteó su posible identificación con un Ecce Homo venerado en el santuario de la Gran Promesa como Cristo de la Humildad, procedente de San Antón (Martín González, 1959: 112-113).

Los siguientes conjuntos, citados por Canesi, son los pasos grandes que poseía la cofradía. El primero representaba a

Longinos a caballo dando la lanzada a Cristo ya crucificado y su Madre Santísima y S. Juan a su vista". El siguiente que representaba el entierro se formaba con "José de Arimatea y Nicodemús con Cristo difunto en los brazos cuando le bajaron de la cruz, la que a su vista, y la Madalena y otra figura abriendo el sepulcro (Canesi, 1996: 25).

Ésta referencias de Canesi han servido para deshacer el tremendo embrollo que rodeaba a estos dos conjuntos, y poder reconstruir parcialmente el segundo paso, del que al menos se conservasen el museo tres figuras completas (Cristo, Nicodemo y María Magdalena) además de la cabeza de José de Arimatea. El conjunto hoy conocido en su versión reducida (prescindiendo de la Magdalena) como Cristo de la Cruz a María, en detrimento a su antigua titulación, está documentado como obra de Antonio de Ribera y Francisco Fermín, realizado entre 1641-1642 (Rojo Vega, 1999, p. 173).

Del paso de Longinos, tan destrozado que ha sido imposible recomponer (solo conservamos las imágenes de la Virgen, San Juan y la figura de Longinos, sin 


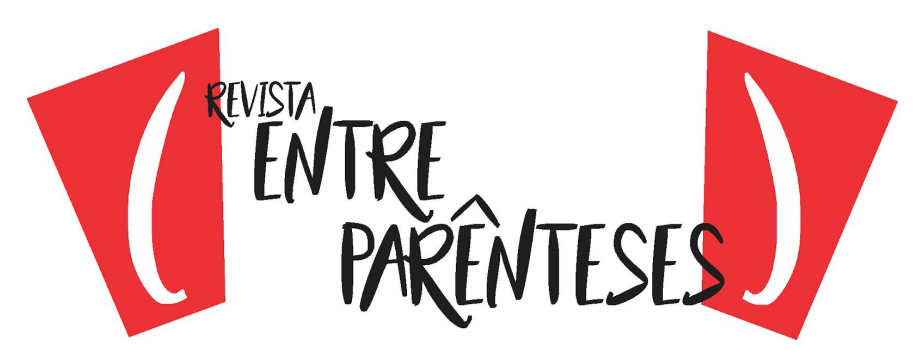

caballo en Museo Nacional de Escultura), se conoce como era en líneas generales por las réplicas realizadas por Andrés Oliveros y Pesquera en 1673 para Medina de Rioseco, (sustituidas las imágenes de la Dolorosa, San Juan y la Magdalena en el siglo XVIII por Tomas de Sierra) y José de Rozas y Antonio Vázquez para Palencia en 1692, mientras que su autoría sigue confusa si bien próxima al círculo de oficiales más directos a Gregorio Fernández. (Andrés Ordax, 1994: 100).

El último paso, el de "Nuestra Señora de la Soledad a vista de la Cruz, desconsolada por la injusta muerte de su hijo amado" (Canesi, 1996: 24), está actualmente sin identificar. Según la documentación se conoce que aún existía en 1900 en la iglesia de San Antón (González García-Valladolid, 1900, p. 709). Se supone que la imagen de vestir de la Virgen sería similar al antiguo paso de Medina de Rioseco, conocido por una antigua fotografía. Este paso junto con el Cristo de la Humildad eran los elegidos en momentos de crisis, para sacar en procesión, al ser menos pesados que los dos otros conjuntos y necesitar menor porteadores para llevarlos (Pérez, 1885: 143).

Junto con la Piedad, es la cofradía de Jesús Nazareno, de la que menos información nos suministra las fuentes acerca de los pasos procesionales. La mayoría de los escritores y tratadistas solo mencionan que en la ermita de Jesús Nazareno también había obras de estas características (Ponz, 1788: 57; Ceán, 1800: 267 y Beristáin, 1933: 203), sin especificar nada más. Volviendo a los pasos procesionales, las únicas referencias que tenemos son las proporcionadas por Canesi, al describir el cortejo procesional que hacía la cofradía en la mañana del Viernes Santo. Constaba la procesión de solo tres pasos, el del Nazareno, cuando estaban abarrenando la cruz para ponerle en ella. Cristo crucificado y un judío clavando el rótulo en lengua hebrea, griega y latina, y dos sayones partiendo la túnica y jugándosela a los dados (Canesi, 1996: 24-25). 


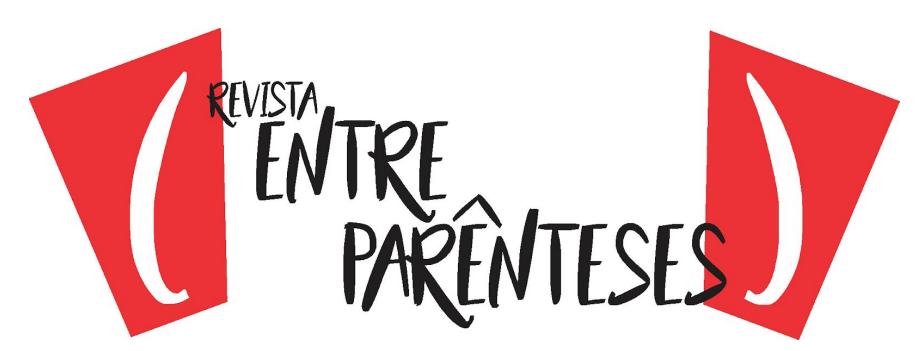

La imagen de Jesús que "conmueve a mucha devoción por su admirable hechura", se entronizó en 1704 en el retablo mayor de estilo barroco, que tanto admiró Canesi, y que tanto horrorizó a Ponz. En el incendio declarado en 1799, debió queda dicho retablo dañado por el fuego, aunque no destrozado, hecho que fue aprovechado para ser sustituido por otro de líneas neoclásicas que haría las delicias de los más recalcitrantes ilustrados, y que aún sirve de marco a la imagen del Nazareno (Ponz, 1788: 57). La autoría de la talla ha sido de lo más polémica. Respecto a ella se han barajado distintos escultores, aunque hoy en día se suele admitir de manera general su atribución a Juan Antonio de la Peña, que trabajó para la cofradía entorno a la década de los 80.

El segundo paso citado por Canesi es el hoy llamado Preparativos para la Crucifixión, conservado en el Museo Nacional de Escultura. El paso fue estrenado en 1680 y se debe a la mano de Juan de Ávila. No obstante, el Cristo Original del Paso desapareció en el incendio de 1799, encargándose en 1801 al escultor Claudio Cortijo una copia para sustituir la imagen perdida. Pese a ello es poco probable, debido a la crisis que sacudía a las procesiones, que la nueva imagen llegó a montarse en algún momento en el paso para el que estaba destinada. En el siglo XX. Con la reconstrucción de los pasos, ya en el Museo, por Agapito y Revilla, eta imagen del Cristo del Despojo, que estaba a la veneración en su iglesia de Jesús fue sustituida por un Ecce Homo atribuido a Alonso de los Ríos. Por su parte la descripción del tercer paso, conocido como "Sed Tengo", resulta ser de extraordinario valor, pues se ha documentado como obra de Gregorio Fernández (Urrea, 1973: 405 y Luna Moreno, 1986: 79-81). El maestro logró imponer una figura de difícil equilibrio, logrando la mayor verticalidad conseguida en un paso procesional.

\section{CONCLUSIONES}

A lo largo de presente texto, hemos podido poner de manifiesto las 


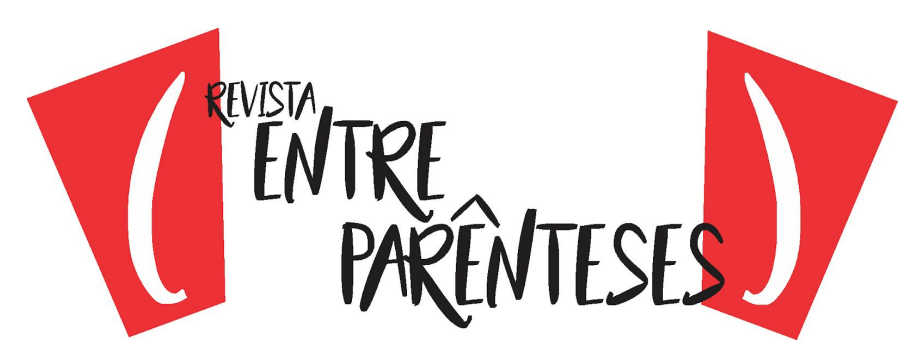

múltiples relaciones que existen ente el hecho literario y la realidad escultórica. Aunque tales influencias son constantes a lo largo de la historia, podemos encontrar momentos y localizaciones donde el correlato literario y el debate intelectual por escrito adquieren tintes de conflicto social. Uno de los casos más paradigmáticos es el que aquí hemos analizado, el del Valladolid del siglo XVIII, donde la literatura siguió repitiendo hasta la saciedad la continua hegemonía de Gregorio Fernández desde el siglo anterior. En algunos casos, la discusión literaria puso entre dicho las atribuciones al maestro, proponiendo otros nuevos autores. En cualquier caso, todo este aireado debate ha sido zanjado a posteriori con las aportaciones documentales de los investigadores.

\section{REFERENCIAS}

ACEVEDO, M. Canesi. Historia Secular y Eclesiástica de la muy antigua, augusta, coronada, muy ilustre, muy noble, rica y muy leal ciudad de Valladolid. Valladolid: Grupo Pinciano, Caja España y Ayuntamiento de Valladolid, 1996.

AGAPITO y Revilla, J. Las cofradías, las procesiones y los pasos de Semana Santa de Valladolid. Valladolid: Imprenta Castellana, 1925.

J. Museo Provincial de Bellas Artes de Valladolid. Catálogo de la Sección de Escultura. Valladolid: Imprenta F. Zapatero, 1916.

ALMUIÑA, C. Manuel Canesi Acebedo y sus coordenadas historiográficas. En Canesi Acevedo, M. (1996). Historia Secular y Eclesiástica de la muy antigua, augusta, coronada, muy ilustre, muy noble, rica y muy leal ciudad de Valladolid. Valladolid: Grupo Pinciano, Caja España y Ayuntamiento de Valladolid, 1996.

ANÓNIMO. Compendio Histórico y descriptivo de Valladolid. Valladolid: Imprenta Julián Pastor, 1843.

BERISTÁIN, J. M. (1933). Diario Pinciano, Histórico, literario, legal, político y económico. Primer diario de Valladolid. Valladolid: Imprenta Castellana, 1933.

J. M. Diario Pinciano, Histórico, literario, legal, político y económico.

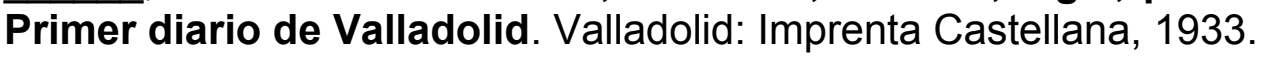




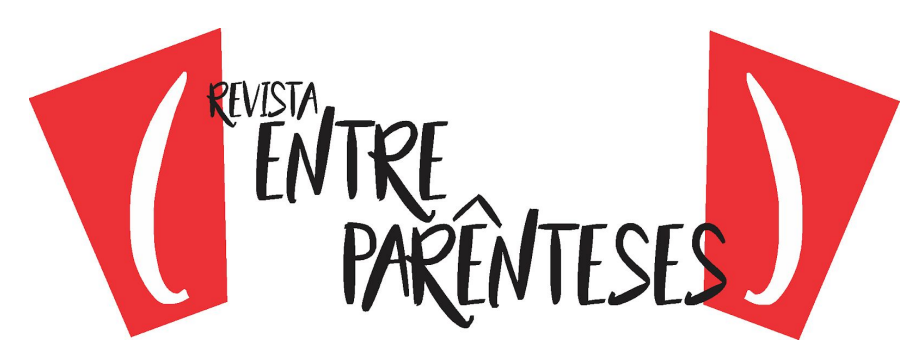

BERMÚDEZ, J. A. Ceán. Diccionario Histórico de los más ilustres profesores de las Bellas Artes en España. Madrid: Viuda de Ibarra, hijos y compañía, 1800.

BOSARTE, I. Viaje artístico a varios pueblos de España. Con el juicio de las obra de las nobles artes que en ellos existen y épocas a que pertenecen. Viaje a Segovia, Valladolid y Burgos. Madrid: Imprenta Real, 1804.

CANDEIRA y Pérez, C. Guía del Museo Nacional de Escultura de Valladolid. Valladolid: Gráficas Relinguer, 1945.

CANTERO, A. Prieto. Historia de la Real Academia de Nobles y Bellas Artes de la Purísima Concepción de Valladolid. Valladolid: Diputación de Valladolid, 1983.

CASTRO, A. Palomino. Vidas. Madrid: Alianza Forma, 1986.

CHICO, E. García. Cofradía Penitencial de Nuestra Señora de las Angustias. Valladolid: Sever-Cuesta, 1964.

, E. García. Documentos para el estudio del arte en Castilla. Tomo II. Escultores. Valladolid: Gráficas Afrodísio Aguado, 1941.

, E. García. La Cofradía Penitencial de la Santa Vera Cruz. Valladolid: Gráficas Andrés Martín, 1962.

, E. García. Valladolid. Papeletas de historia y arte. Valladolid: Gráficas Andrés Martín, 1958.

CORTES, Alonso. N. Introducción a la edición facsímil del Diario Pinciano.

EGIDO, T. Introducción a la edición facsímil del Diario de Valladolid, de Ventura Pérez. En: Pérez, V. Diario de Valladolid. Valladolid: Editorial Grupo Pinciano, 1983, pp. I-XIV.

, T. La religiosidad colectiva de los vallisoletanos. En: Valladolid en el siglo XVIII. Valladolid: Ateneo de Valladolid, 1984, pp. 157-260.

FERNÁNDEZ, J. Urrea. Conservación y Exposición de los pasos en el museo. Pasos Restaurados. Valladolid: Museo Nacional de Escultura, 2000, pp. 11-24.

J. Urrea. El escultor Francisco de Rincón. Boletín del Seminario de Estudios de arte y Arqueología, nº 39, pp. 491-500, 1973.

, J. Urrea. Nuevos datos del escultor Andrés Solanes. Boletín del Seminario 


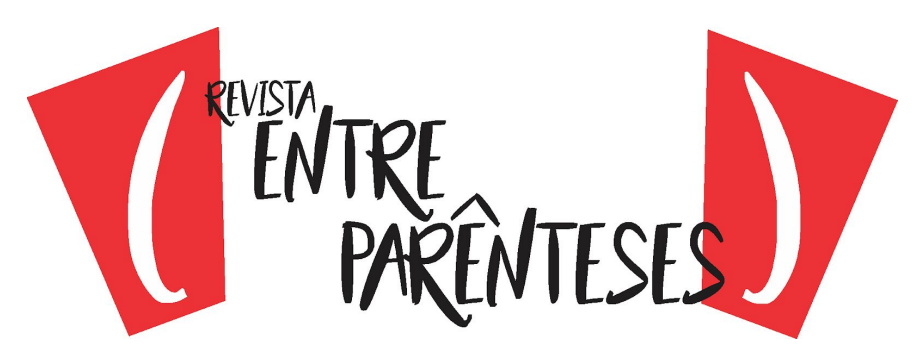

de Estudios de arte y Arqueología, n 55, pp. 181-188, 1989.

J. Urrea. Aproximación biográfica al escultor Gregorio Fernández. En: Gregorio Fernández. 1576-1636. Madrid: Fundación BSCH, 1999, pp. 14-41.

J. Urrea. En torno a Gregorio Fernández. Boletín del Seminario de Estudios de arte y Arqueología, n 39, pp. 245-260, 1973.

FONTÁN, N. Costas. Las series de la tercera edad de oro de la ficción televisiva. Cambia la forma de ver televisión. El referente estadounidense: Games of thrones. (Tesis Doctoral). Universidad de Vigo: Pontevedra, 2015.

GARCÍA-VALLADOLID, C. González. Valladolid, Recuerdos y Grandezas. Valladolid: Imprenta de Juan R. Hernando, 1900.

GONZÁLEZ, J. J. Martín, Urrea Fernández, J. Catalogo Monumental de la provincia de Valladolid. Tomo XIV. Valladolid: Diputación de Valladolid, 1985.

, J. J. Martín. El escultor Gregorio Fernández. Madrid: Dirección General de Bellas Artes. Ministerio de Educación y Ciencia, 1980.

, J. J. Martín. Escultura Barroca Castellana. Tomo I. Madrid: Publicaciones de la Colección Lázaro Galdiano, 1959.

, J. J. Martín. Juan de Juni. Vida y obra. Madrid: Dirección General de Bellas Artes. Ministerio de Educación y Ciencia, 1974.

J. J. Martín. Una plancha de grabado de Nuestra Señora de la Pasión. Boletín del Seminario de Estudios de arte y Arqueología, n 48 , pp. 405-408, 1982.

HERRERO, J. Sánchez. La Semana Santa de Sevilla. Madrid: Silex, 2003.

HOYO, M. A. Fernández Del. El Cristo del Perdón obra de Bernardo del Rincón. Boletín del Seminario de Estudios de arte y Arqueología, $n^{\circ} 49$, Págs. 476-481, 1983.

M. A. Fernández Del. El escultor vallisoletano Francisco Diez de Tudanca (1616- $i)$. Boletín del Seminario de Estudios de arte y Arqueología, $n^{\circ} 50$, pp. 371-388, 1984.

MONSÓ, J. Martí. Estudios Histórico Artísticos relacionados principalmente con Valladolid. Valladolid: Leonardo Miñón, 1898-1901. 


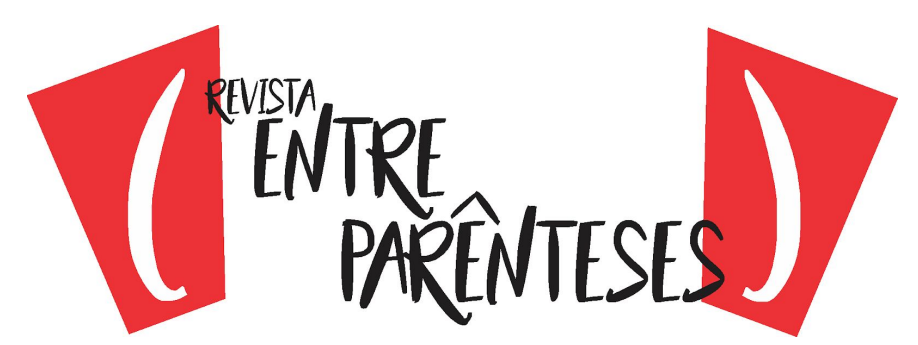

MORENO, L. Luna, González, R. Fernández. Gregorio Fernández y la Semana Santa de Valladolid. Valladolid: Sever-Cuesta, 1986.

ORDAX, S. Andres. Semana Santa en Medina de Rioseco. En: Semana Santa en Castillas y León. Valladolid: Junta de Castilla y León y Edilesa, 1993, pp. 91-103.

PÉREZ, V. Diario de Valladolid. Valladolid: Imprenta y Librería Nacional y Extranjera de Hijos de Rodríguez, 1885.

PONZ, A. Viaje de España. En que se da noticia de los casos más apreciables y dignos de saberse que hay en ella. T. XII. Madrid: Viuda de lbarra, hijos y compañía, 1788.

RECIO, L. Enciso. Valladolid en el Siglo XVIII. Valladolid: Ateneo y Ayuntamiento de Valladolid, 1984.

VAL, J. D. \& Catalapiedra, F. Semana Santa de Valladolid. Pasos, cofradías e imagineros. Valladolid: Lex Nova, 1970.

VIÑAZA, Conde de la. Adiciones al Diccionario histórico de los más ilustres profesores de las Bellas Artes de don Juan Agustín Bermúdez. Madrid: Tipografía de Huérfanos, 1989.

VEGA, A. Rojo. Fiestas y comedias en Valladolid. Siglos XVI y XVII. Valladolid: Ayuntamiento de Valladolid, 1999.

VEGA, B. García. Nuestra Señora de la Pasión de Valladolid. Estudios de Arte en Homenaje al profesor Martín González. Valladolid: Universidad de Valladolid, 1995, pp. 615-623).

VEIGA, T. Pinheiro Da. La Fastiginia o Fastos geniales, vida en la corte de Valladolid. Valladolid: Imprenta Colegio de Santiago. 1916.

WATTENBERG, F. Museo Nacional de Escultura de Valladolid. Madrid: Aguilar. S.A, 1963.

Recebido em: 28/06/2019

Aceito em: 20/08/2019 